Portland State University

PDXScholar

\title{
The morphology, physiology, and fine structure of a toluene-oxidizing strain of Pseudomonas putida
}

\author{
Barry Clayton Anderson \\ Portland State University
}

Follow this and additional works at: https://pdxscholar.library.pdx.edu/open_access_etds

Part of the Bacteriology Commons, and the Biology Commons

Let us know how access to this document benefits you.

\section{Recommended Citation}

Anderson, Barry Clayton, "The morphology, physiology, and fine structure of a toluene-oxidizing strain of Pseudomonas putida" (1992). Dissertations and Theses. Paper 4247.

https://doi.org/10.15760/etd.6131

This Thesis is brought to you for free and open access. It has been accepted for inclusion in Dissertations and Theses by an authorized administrator of PDXScholar. Please contact us if we can make this document more accessible: pdxscholar@pdx.edu. 
AN ABSTRACT OF THE THESIS OF Barry Clayton Anderson for the Master of Science in Biology presented Septembsr 18, 1992.

Title: The Morphology, Physiology, and Fine Structure of a Toluene-oxidizing Strain of Pseudomonas putida.

APPROVED BY THE MEMBERS OF THE THESIS COMMITTEE:
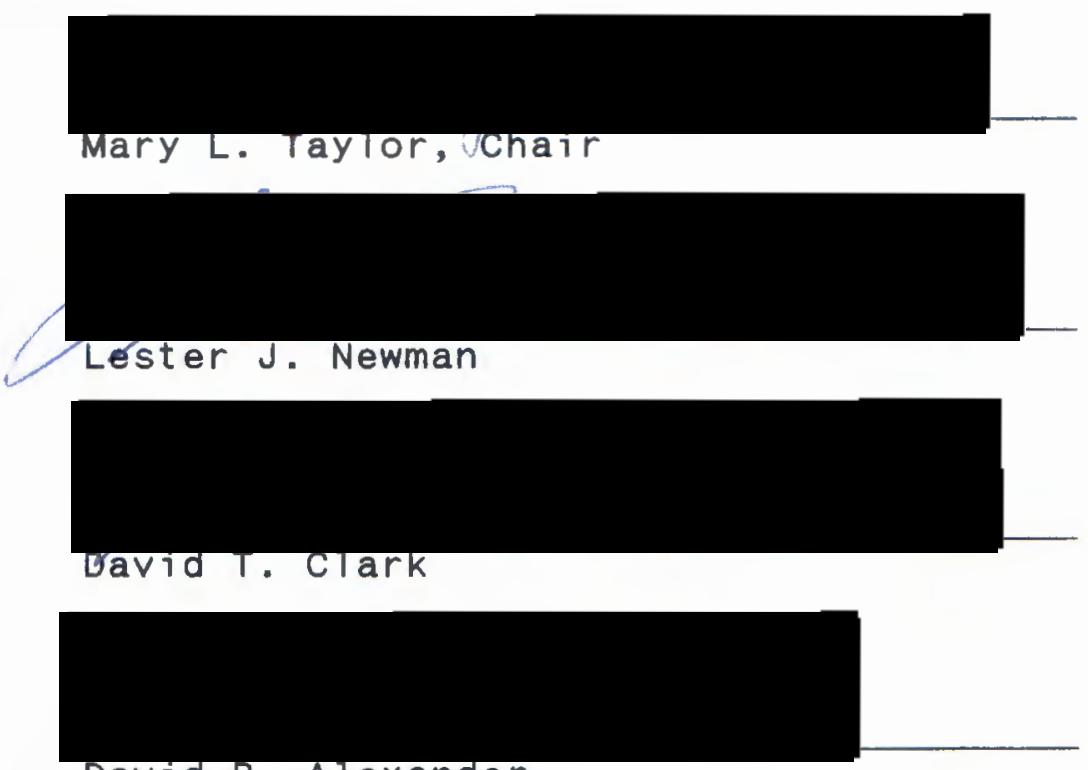

David B. Alexander

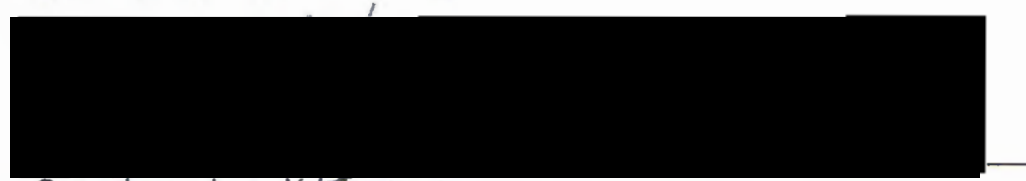

Gordon L. KTIgour

The role of microorganisms in the degradation of xenobiotics in the environment is well established. Bacteria from the genus Pseudomonas are particularly well adapted to the degradation of hydrocarbons, aromatics, and numerous other natural and introduced substrates. We have isolated a 
strain of Pseudomonas putida, designated PC2P15, that uses toluene, phenol, benzene, and a number of other substrates as its sole sources of carbon and energy.

Morphological, biochemical, and metabolic analysis of PC2P15 has revealed significant changes in the fatty acid content, the presence of extracellular membrane vesicles, the possible production of an emulsifying agent and the apparent simultaneous use of multiple metabolites in bacteria exposed to toluene, succinate, or toluene and succinate when compared to those organisms growing in sucrose alone. ${ }^{14} \mathrm{C}$-sucrose uptake in bacteria exposed simultaneously to both sucrose and toluene or sucrose and succinate each showed an approximately $50 \%$ decrease in ${ }^{14} \mathrm{C}-$ sucrose uptake when compared to organisms growing in sucrose alone. Organisms exposed to a combination of sucrose, toluene, and succinate showed an approximately $75 \%$ drop in ${ }^{14} \mathrm{C}$-sucrose uptake when compared to organisms grown in sucrose alone. The addition of cyclic-AMP had no effect on ${ }^{14} \mathrm{C}$-sucrose uptake for any combination of substrates. 
THE MORPHOLOGY, PHYSIOLOGY, AND FINE STRUCTURE

OF A TOLUENE-OXIDIZING STRAIN

OF PSEUDOMONAS PUTIDA

by

BARRY CLAYTON ANDERSON

A thesis submitted in partial fulfillment of

the requirements for the degree of

\author{
MASTER OF SCIENCE \\ in \\ BIOLOGY
}

Port 1 and State University

1992 
TO THE OFFICE OF GRADUATE STUDIES:

The members of the committee approve the thesis of

Barry Clayton Anderson presented September 18, 1992.
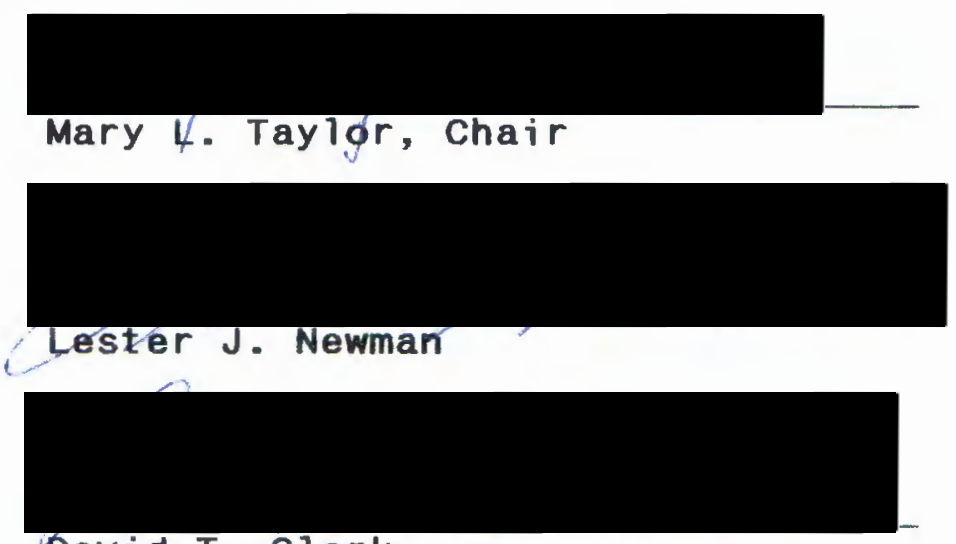

David T. Clark

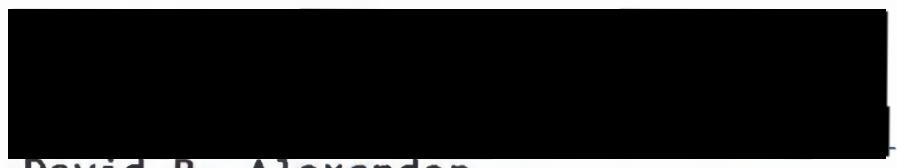

David B. Alexander

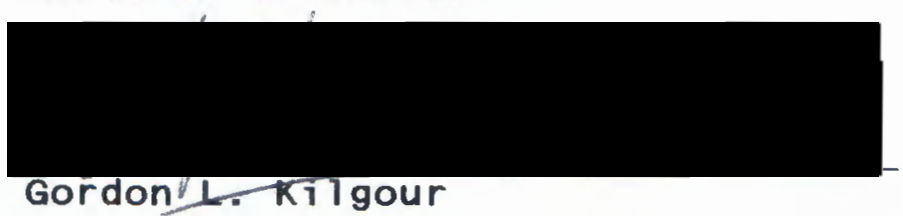

APPROVED:

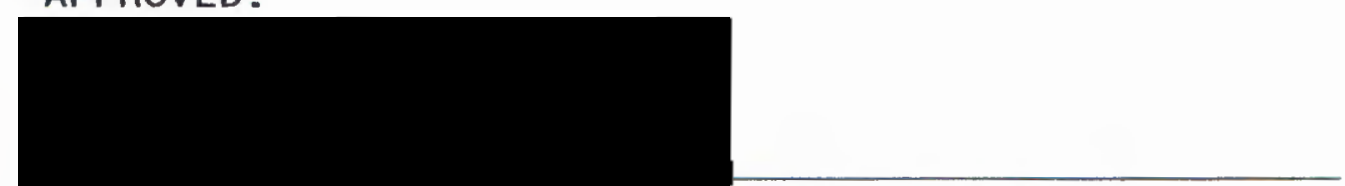

Richard Forbes, Chair, Department of Biology

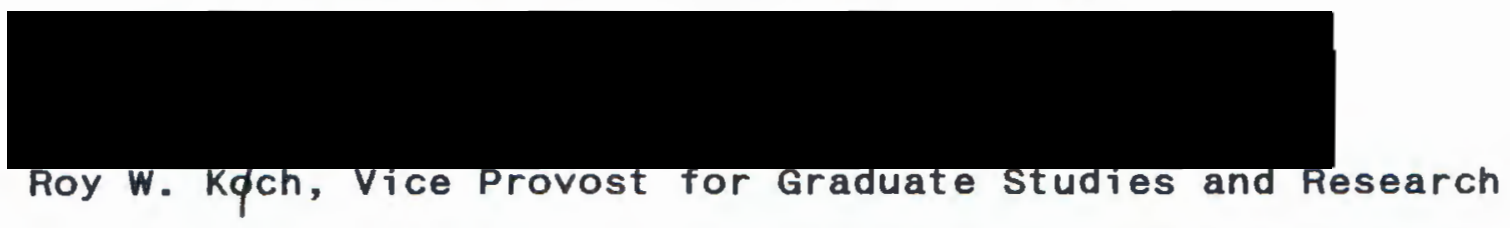




\section{DEDICATION}

I dedicate my research and this Thesis to my wife, claire Roff Anderson, whose love and unwavering support have allowed me to pursue my dreams.

I also dedicate this Thesis to my parents, Virginia Hyatt Anderson and Wallace Julian Anderson, for their love and continued belief in me throughout my 1 ife and in the midst of many storms. 


\section{ACKNOWLEDGEMENT}

I would like to acknowledge Dr. Mary L. Taylor of the Port 1 and State University Department of Biology for her help and encouragement in the preparation of this Thesis and for her intellectual contributions to the research upon which this Thesis is based. 


\section{TABLE OF CONTENTS}

PAGE

ACKNOWLEDGEMENT $\ldots \ldots \ldots \ldots \ldots \ldots \ldots \ldots \ldots \ldots \ldots \ldots \ldots \ldots$ i $i$

LIST OF TABLES....................... vi

LIST OF FIGURES....................... vii

INTRODUCTION. . . . . . . . . . . . . . . . . . . 1

Bioremediation..................... 1

The Pseudomonads...................... 6

Biochemistry of Aromatic Degradation.......... 7

Research Focus..................... 11

MATERIALS AND METHODS.................... 13

Isolation, Identification, and Testing........ 13

Growth and Protein Analysis.............. 16

Microscopic Analysis.................... 20

Metabolic Analysis.................... 20

RESULTS........................... 22

Identification of PC2P15............. 22

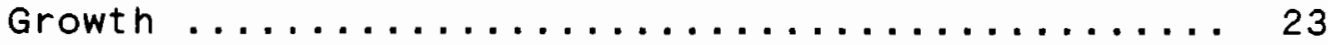

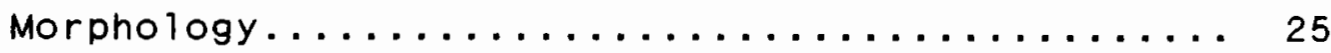

Fatty Acid Profile................... 33

Metabolic and Protein Analysis........... 35

Catabolite Repression ................. 35 
PAGE

DISCUSSION.

Morphology and Metabolic stress.............. 41

Cytoplasmic Proteins.................... 46

Metabolism of Multiple Carbon Sources......... 48

CONCLUSIONS AND SUMMARY ..................... 51

REFERENCES................................... 54 


\section{LIST OF TABLES}

\section{TABLE}

PAGE

I Modified Bushnel1-Hass Formulation............. 14

I I Standard Tests To Identify Isolate.............. 15

I I Substrate Utilization By PC2P15............... 17

IV ${ }^{14} \mathrm{C}$-Sucrose Uptake in PC2P15............... 36 


\section{LIST OF FIGURES}

F IGURE

PAGE

1 Locations of Marine $0 i 1$ Seeps................. 2

2 Summary of Aromatic Catabolic Pathways........... 9

3 Growth of P.putida PC2P15................... 24

4 BCA Protein Assay of P.putida PC2P15........... 26

5 Light Micrographs of P.putida PC2P15........... 27

6 Electron Micrograph of PC2P15 Grown in Toluene.... 28

7 Electron Micrograph of PC2P15 Grown in Sucrose.... 29

8 Electron Micrograph of PC2P15 Grown in Toluene.... 30

9 Fatty ACid Profile of PC2P15................ 34

$10 \quad{ }^{14} \mathrm{C}$-Sucrose Uptake in P.putida PC2P15.......... 38

$11{ }^{14} \mathrm{C}$-Sucrose Uptake in P.putida With C-AMP Added.... 39 


\section{INTRODUCTION}

\section{BIOREMEDIATION}

Increasing contamination of soils and water with toxic pollutants including the seepage of oil (Figure 1) has greatly increased interest in the role of microbial communities in the degradation and bioremediation of toxic organic molecules and various recalcitrant aromatic compounds. This problem was brought to the forefront on 24 March 1989 when the oil tanker Exxon Valdez ran aground in Prince William Sound, Alaska. Massive cleanup efforts included the use of bacteria to degrade a portion of the eleven million gallons of crude oil spilled into the previously pristine sound. Initially, some success was achieved through the use of both water soluble and oleophilic fertilizers to enhance bioremediation using naturally occurring soil organisms $(1,40,60)$. Despite these promising initial results, many of the factors governing in situ bioremediation remain unknown.

A number of parameters must be considered when inoculating a culture enriched for a particular hydrocarbon into a contaminated site. The success of the bioremediation effort may be influenced by predation and competition or by abiotic stresses for introduced organisms such as low 


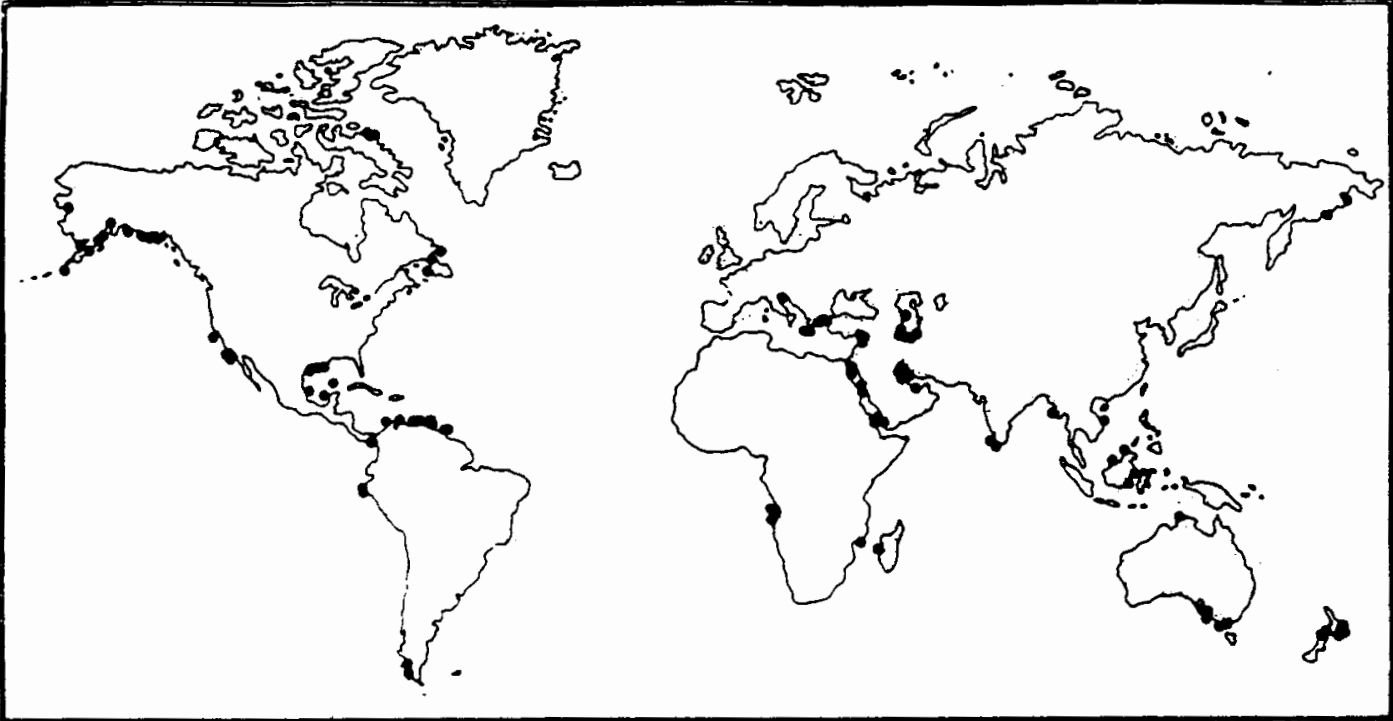

Figure 1. Locations of marine oil seeps. ( $0 i 1$ in the Sea: Inputs, Fates, and Effects, 1985. p.47 (63).) 
nutrient levels, high contaminant levels, toxins, or the preferential use of other organic compounds (57).

Many investigators are attempting to understand the basic physiology and metabolism of those microorganisms capable of degrading hydrocarbons both in situ and in the laboratory $(10,11,12)$. A recent study by $\mathrm{Hill}$ (2) indicated the presence of Alcaligenes $A 5$ and a number of other biodegradative organisms in an area contaminated with 4chlorobiphenyl. Most probable number for growth on polychlorinated biphenyl (PCB) followed by gene probe analysis revealed the presence of the $4 \mathrm{CB}$ plasmid, which codes for the degradation of $P C B$, scattered throughout the indigenous populations.

In another study, enrichment isolates of selected strains of Pseudomonas have been used successfully for in situ bioremediation of hydrocarbon-contaminated soil and groundwater in California (3). Some investigators have shown that, in sites where long standing contamination has occurred, populations of soil organisms have adapted to degrade alkanes and aromatics. A recent site survey revealed the presence of 244 gasoline-degrading isolates in an aquifer contaminated with unleaded gasoline (4). The four major genera represented at this site were Pseudomonas, Alcaligenes, Micrococcus, and Nocardia. Madsen (41) has reported the biodegradation of naphthalene in situ in a contaminated aquifer. A recent report indicated that a 
luciferase marker has been placed in a strain of $P$. fiuorescens and currently is being tested as a bioluminescent indicator for naphthalene exposure and degradation (42). Recent reports (58) have shown that there are unanticipated interactions of substrates, products, and organisms in a benzene, toluene, and xylene (BTX) contaminated aquifer which affected both the indigenous and introduced populations. This finding reinforces the fact that bioremediation in natural systems is a complex, multifaceted process in which indigenous or introduced organisms react in ways that are not always predictable from studies done in the laboratory.

Other investigators have reported that a wide variety of compounds are being degraded by naturally occurring soil and water organisms in sites of long standing contamination. Among the compounds that have been found to be degraded are benzoate (44), p-nitrophenol (45), chlorinated biphenyl (46), 1,2,3,-trichloro- and 1,2,4,5,-tetrachiorobenzene (59), and others.

The rapidly growing field of recombinant DNA technology is being exploited in the biodegradation of xenobiotics and toxic waste and shows some promise, although this type of research applied in situ is closely monitored by the EPA (43). Some research has shown, however, that organisms inoculated into contaminated sites are not able to pass on the plasmids containing the genes for the metabolism of 
hydrocarbons with any degree of efficiency in soils. As one might expect, intrageneric transfer is the most efficient, with approximately $10^{-2}$ transfers per transconjugate. However, intergeneric plasmid transfers are reported to be as low as $10^{-7}$ transfers per transconjugate (47). The authors contend that these low figures of 1 plasmid transfer per 100 intragenerically and 1 transfer per 10,000,000 intergenerically may not be abnormal in situ due to the interplay of a multitude of abiotic factors in soils and water.

It has been determined (5) that the rate of degradation of hydrocarbons and organic solvents in situ is controlled by a number of complex factors including concentration of the contaminant(s), temperature, available nutrient levels, emulsification, salinity, and the condition of the soil or water at the site.

Currently, the economic feasibility of microbially mediated bioremediation, microbialiy enhanced oil recovery, and even the use of bacteria in coal bioprocessing is an area of intense research $(6,7)$. Among the bacteria being investigated, those belonging to family Pseudomonadaceae are some of the most promising because of their impressive metabolic capabilities. 


\section{THE PSEUDOMONADS}

den Dooren de Jong in 1926 listed 80 organic compounds used by a species of Pseudomonas (as part of the research for his doctoral dissertation) (10). Other investigators have extended the scope of our knowledge of the physiology and metabolic capabilities of the pseudomonads $(20,21)$. Most of the members of this genus grow quite rapidly on a variety of metabolites, exhibiting growth typical of r-type selection. In the natural environment, r-type organisms with the nutritional versatility of the pseudomonads would be expected to respond to the sudden influx of a new carbon source by outcompeting the more exacting K-type organisms. It is this very versatility that makes the pseudomonads excellent subjects for research not only into their role in bioremediation, but also into the biochemistry, physiology, and genetics of this and other groups of microorganisms in the environment.

Organisms in genus Pseudomonas are gram negative, motile rods. Typically, they display one or more polar flagella. They are absolute respirers and are usually oxidase positive. Pseudomonads never ferment. Some of the members of this group synthesize a yellow-green water soluble pigment that characteristically fluoresces under ultra-violet light. Members of this genus are common, freeliving organisms in soils, fresh or marine waters, and in 
association with plants and animals. With a few exceptions, such as certain strains of $P$. aeruginosa, most members of this genus are not pathogenic. Pseudomonads are capable of great metabolic diversity and are able to use a large variety of organic compounds as sources of carbon and energy. Some strains may utilize as many as one hundred different compounds including sugars, amino acids, hydrocarbons, aromatics, and fatty acids.

\section{BIOCHEMISTRY OF AROMATIC DEGRADATION}

Most naturally formed mono- and polycyclic aromatic compounds result from forest fires, from the combustion of fossil fuels, and from the degradation of 1 ignin by fungi $(8,9)$. It is not surprising that many microorganisms have adapted metabolic pathways capable of degrading these substances, especially when one considers the total amount of hydrocarbons and other organic substances being introduced into the environment every year. For example, it has been estimated that more than one billion gallons of toluene are produced each year by the industrialized nations. This production is accompanied by the spills, dumping, and accidents that are the seemingly inevitable results of human activity.

The benzene nucleus is exceedingly abundant in the biosphere and, because of its resonance structure, is 
extremely stable. Most of the degradation of the benzene nucleus is done by microorganisms $(14,15)$.

As shown in Figure 2 , the prerequisite reaction for the breaking of the benzene nucleus is either a single or double hydroxylation of the ring depending on the substituents present. It was originally believed that the product of the double hydroxylation of benzene was a trans-benzene dihydrodiol $(22,23)$. However, further investigation (16) revealed that a strain of Pseudomonas growing rapidly on toluene would oxidize benzene and catechol, but that transbenzene dihydrodiol was not oxidized at a substantial rate. Other investigators $(17,18)$ showed that a cis-benzene dihydrodiol was formed prior to the formation of catechol and that molecular oxygen was necessary for the hydroxylation reaction. Final proof of cis-benzene dihydrodiol as the pre-catechol intermediate was provided by researchers $(18,39)$ using a mutant strain of $P$.putida deficient in cis-benzene dihydrodiol dehydrogenase.

There are various enzyme systems used by the pseudomonads for the initial hydroxylation(s) of the benzene nucleus. Depending on the substituent groups present on the ring, the organisms may use either a monooxygenase system, a dioxygenase system, or both $(33,35)$.

The dioxygenase system is controlled by the TOD plasmid. The dioxygenase is a three component enzyme system consisting of a flavoprotein reductase, a (2Fe-2S) 


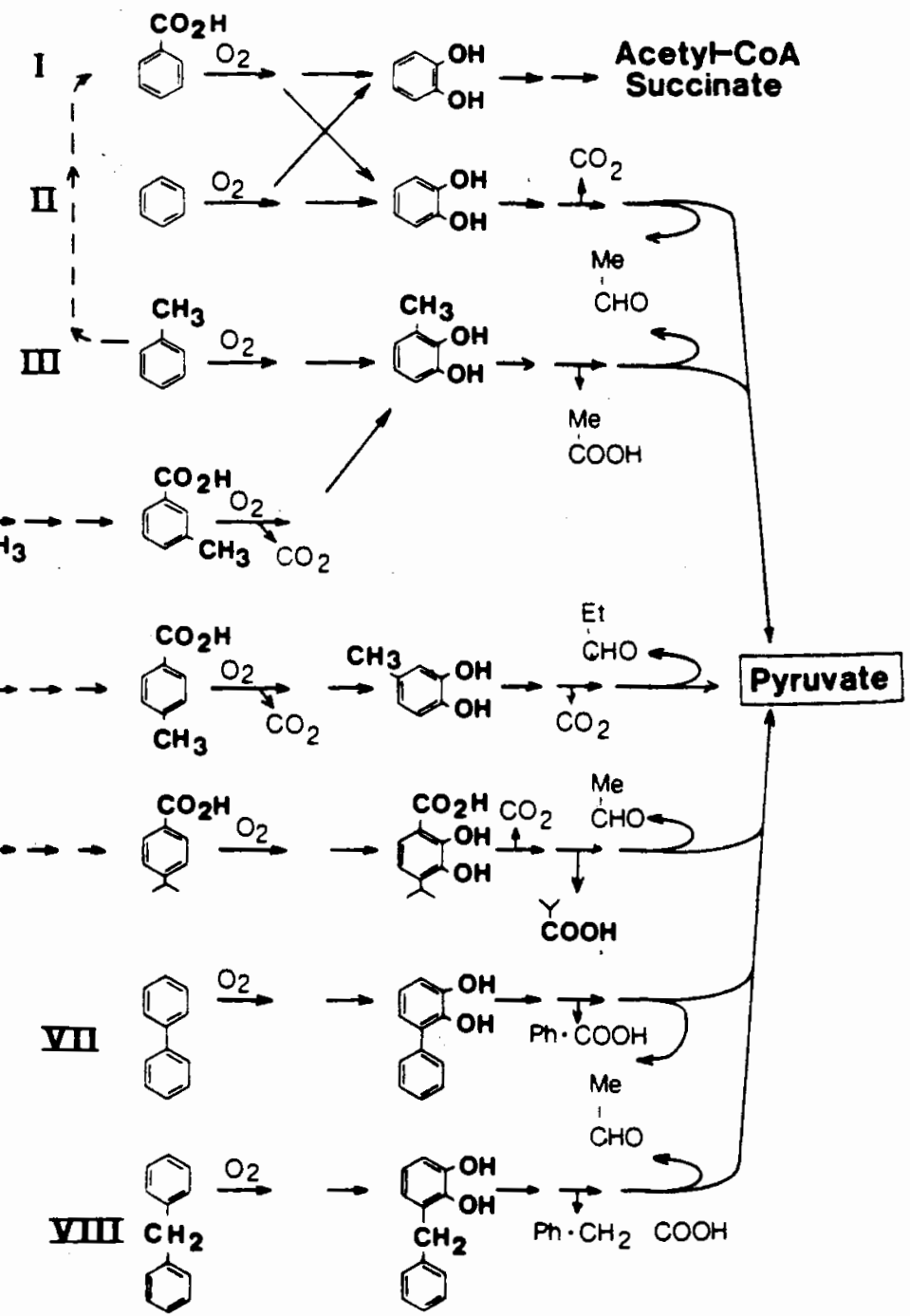

Figure 2. Summary of aromatic catabolic pathways. (From Dagley, S., 1986 (19).) 
ferredoxin designated ferredoxintoL, and an iron-sulfur protein designated ISP $_{\mathrm{TOL}}$. Electrons for this initial reaction, provided by $\mathrm{NADH}$, are transferred to the flavoprotein and then subsequent 1 y passed to the ferredoxin $n_{\text {TOL }}$. The electrons are finally transferred to ISP and then to the cis-toluene dihydrodiol. The dioxygenase pathway forming cis-toluene dihydrodiol is followed by a dehydrogenation of the dihydrodiol by cis-toluene dihydrodiol dehydrogenase $(36,37,38)$.

The monooxygenase is also a three component system (36) controlled by the TOL plasmid. The monooxygenase can form an o- or p-creosol, benzyl alcohol, or other intermediate as the initial product (36).

There are at least two major ways in which the benzene nucleus is cleaved following the formation of the catechol, protocatechuate, or other intermediate. Ortho-fission breaks the ring between the pair of hydroxyl groups which are almost always on adjacent carbons. Meta-fission opens the ring between an hydroxyl group and a non-hydroxyl substituent on the ring.

ortho-fission is somewhat restricted in the degradation of hydrocarbons because of the seeming intolerance of the ortho-fission enzymes to the presence of substituent groups on the ring. Meta-fission enzymes generally tolerate the presence of methyl groups and other substituents, as is the case with the degradation of toluene. 
In the case of benzene, ortho-fission of the catechol gives rise to cis, cis-muconic acid and then to betaketoadipate. Further reactions form the Krebs cycle intermediates succinate and acetyl-CoA. Meta-fission of the catechol leads to the formation of 2-hydroxy-cis, cismuconic semialdahyde and then to acetoacetate, acetaldehyde, and pyruvate, and enters the Krebs cycle as acetyl-CoA (24).

\section{RESEARCH FOCUS}

Our laboratory has isolated a strain of Pseudomonas putida from the soil surrounding a bioremediation pond in Eugene, Oregon. This strain metabolizes a variety of straight and branched chain hydrocarbons and aromatics, including up to $50 \%(v / v)$ toluene as the sole sources of carbon and energy. Other investigators (13) have shown that certain strains of P.putida can withstand a $30-50 \%(\mathrm{~V} / \mathrm{V})$ toluene exposure and apparently thrive.

The focus of our research has been the investigation of how these organisms not only survive direct exposure to highly toxic organic solvents such as toluene, but how they are able to emulsify or partition the toluene molecule for use in their metabolism. We have asked how these solvents affect the outer membrane and have sought to discover the role of toluene exposure and metabolism in the physiological processes and fine structures of these bacteria. We have investigated changes in membrane fatty acid content, the 
production of an emulsifying agent or agents, the significant depression of sucrose uptake in the presence of toluene and $\backslash$ r succinate, and the apparent simultaneous use of multiple metabolic pathways. We have looked at the relatively dramatic changes in their overall morphology and growth rate when compared to control organisms. We have also investigated the role of toluene as it relates to metabolic stress and compared our findings with the findings of other researchers studying the role of nutrient deprivation and metabolic stress on the physiology of microorganisms in the environment $(30,31,32)$. 


\section{MATERIALS AND METHODS}

ISOLATION, IDENTIFICATION, AND TESTING

Soil samples were taken from a bioremediation pond in Eugene, Oregon which was contaminated with various hydrocarbons including trichloroethylene. We used standard enrichment techniques to select an organism capable of growth in a modified Bushnell-Hass Medium with toluene as the sole source of carbon and energy.

The isolate was grown in $20 \mathrm{ml}$ of a slightly modified Bushnell-Hass (mBH) minimal salts media ( $\mathrm{pH} 7$ ) (Table I) with various hydrocarbons as the sole source of carbon and energy. All chemicals and reagents used were analytical or molecular biology grade unless otherwise indicated. Toluene was supplied to the organisms as the vapor in $125 \mathrm{ml}$ side-arm flasks. The bacteria were grown at room temperature and aerated by shaking at 100 rom on a New Brunswick Model s-3 rotating shaker. In tests requiring direct exposure to toluene as the liquid, the organisms were grown in $125 \mathrm{ml}$ Erlenmeyer flasks at room temperature and aerated at $100 \mathrm{rom}$. The exponentially growing cultures were passaged every 72 hours following a characteristic 48 hour 1 ag phase.

Standard tests were performed to identify the isolate (Table II). These tests included a test for motility in 
TABLE I

MODIFIED BUSHNELL-HASS FORMULATION

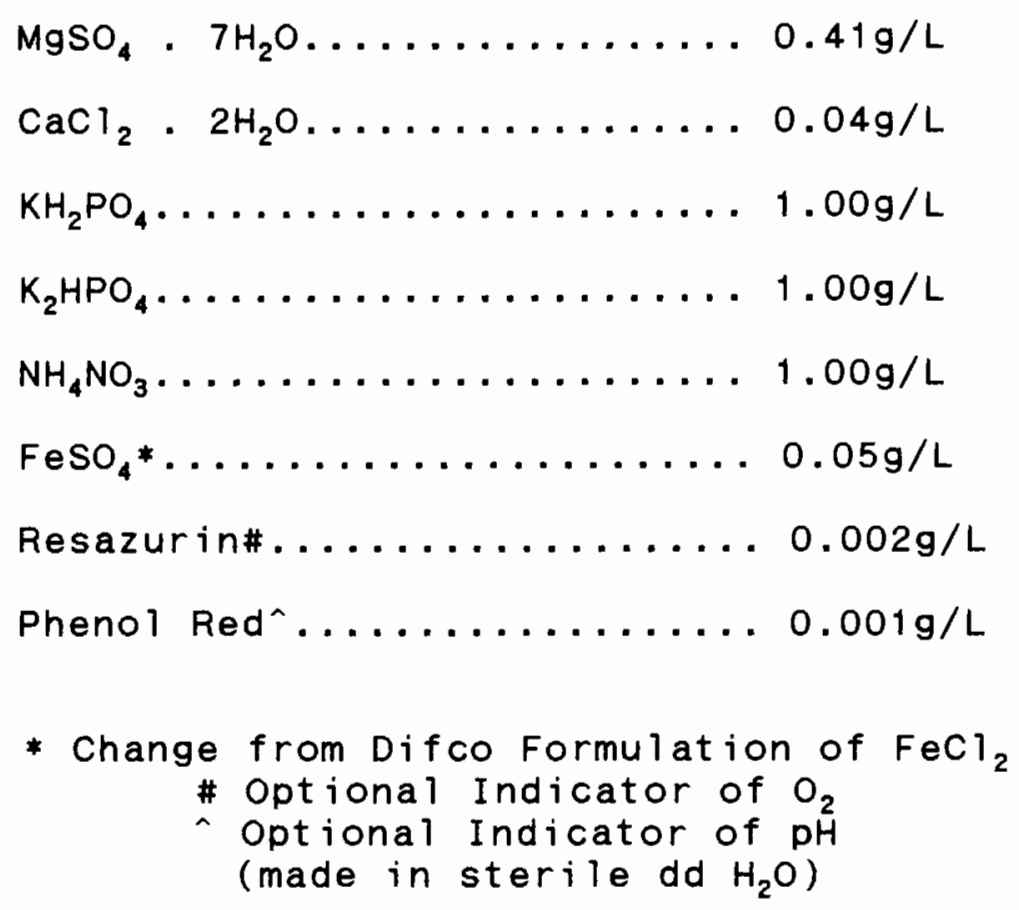


TABLE I I

STANDARD TESTS TO IDENTIFY ISOLATE

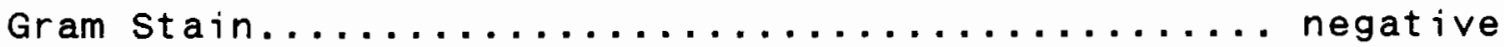

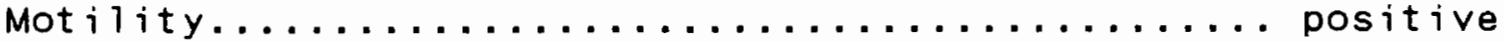

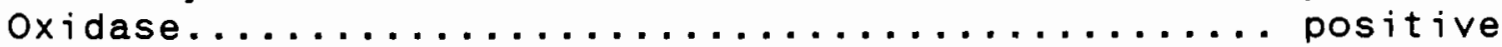

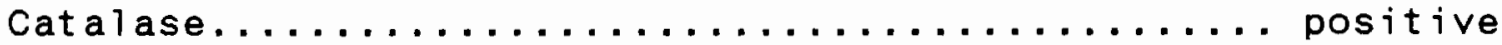

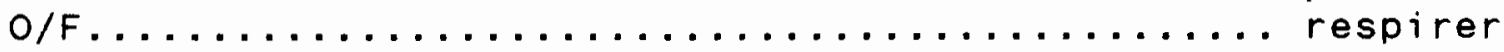
Morphology........................... rod

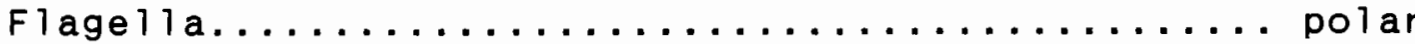

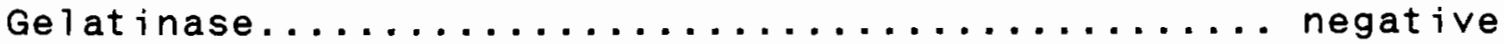

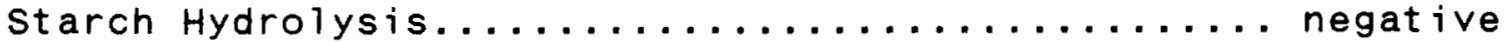

Siderophore Production..................... positive

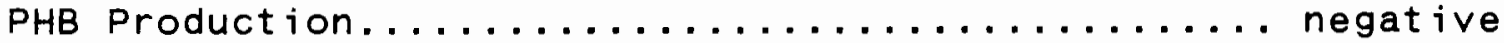

Fluorescence.......................... positive

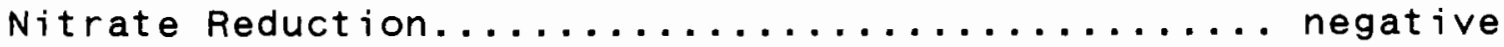

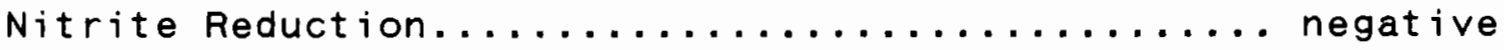

GROWTH TEMPERATURES (in degrees centigrade)

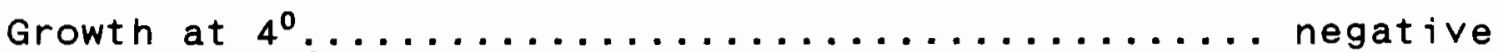
Growth at $10^{0} \ldots \ldots \ldots \ldots \ldots \ldots \ldots \ldots$ negative

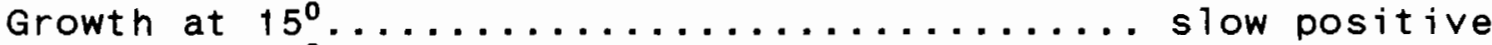

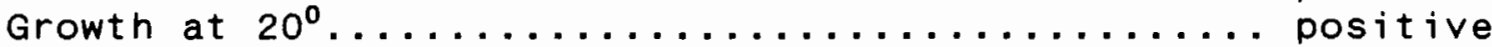

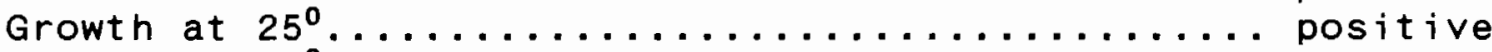

Growth at $32^{0} \ldots \ldots \ldots \ldots \ldots \ldots$ slow positive

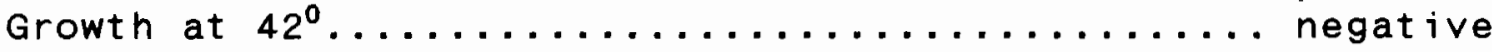

OTHER

Fatty Acid Analysis.................... 81\% positive Pseudomonas putida 
tubes of motility agar, gross colony morphology on plates of nutrient agar, Luria agar, TGYE agar, CAS agar (55) for the production of siderophores, and King's B agar for the test for fluorescent pseudomonads. The isolate exposed to toluene while growing on agar was grown on $\mathrm{mBH}$ with $1.5 \%$ DIFCO certified agar. The bacteria were streaked onto a sterile Nucleopore $0.224 \mathrm{M}$ filter and placed in an enclosed glass tank with toluene vapors and incubated at room temperature. It should be noted that, in all cases when toluene was used as the substrate, the use of glass plates and other utensils was necessary due to the destructive effect of toluene on most plastics. The Nucleopore filter was not significantly affected by toluene during the required growth period. The isolate was tested with various hydrocarbons as the sole source of carbon and energy using the $\mathrm{mBH}$ minimal salts medium (Table III). Control organisms were grown in $\mathrm{mBH}$ with sucrose as the sole source of carbon and energy unless otherwise indicated.

\section{GROWTH AND PROTEIN ANALYSIS}

Growth rate studies were performed in $20 \mathrm{~m} 1 \mathrm{mBH}$ medium with toluene as the sole source of carbon and energy, incubated at room temperature and aerated at $100 \mathrm{rpm}$ as described above. Controls were grown in mBH medium with sucrose. Turbidity was measured on a klett-summerson Photoelectric colorimeter using both a red and purple 
TABLE I I I

SUBSTRATE UTILIZATION BY PC2P15

Sugars and Other Metabolites

Giucose

Sucrose

Maltose

Galactose

Tryptose

Urea

AC Media

AC Media + Glucose

Agars

TGYE

Luria

Nutrient

Blood

Pseudomonas Isolation

Soil Extract

Nutrient $+5 \% \mathrm{NaCl}$

Hydrocarbons and Aromatics

Toluene

p- and $\underline{0}-x y l$ ene

$2,4-\mathrm{D}$

$2,4,5-\mathrm{T}$

Motor oil

Diese 1

Un leaded gasoline

Hexane

Dodecane

Phenol 7\% $(v / V)$

Phenol 2.5\% ( $\mathrm{v} / \mathrm{v})$

Benzene

Catechol 5\% ( $v / v)$

Benzoic acid

Crude $0 i 1$

1,3-DCE

p-amino salicylic acid
Lag Time*

3

$<1$

$<1$

$<1$

$<1$

$<1$

-

3

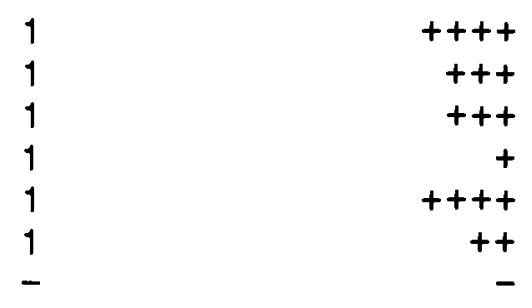

2
3

17

$-$

6

6

5

$-$

5

-

12

2

1

8

11

31
Growth

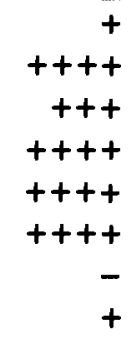

$+$

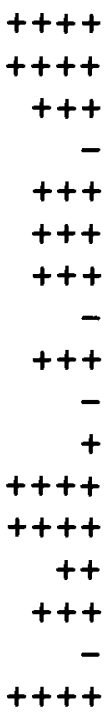

* =approximate lag time in days:toluene inoculum (as measured by turbidity or the appearance of colonies) 
filter. Measurements were taken every two hours for the first eight hours, every four hours for the next sixteen hours, and every twelve hours thereafter for a total of nineteen readings. The growth rate study was performed twice and the figures averaged.

Fatty acid analysis and tentative identification of this isolate was kindly performed by Warren L. Landry of the Food and Drug Administration Laboratory in Dallas, Texas. The analysis used a Hewlett-Packard MIS GC and MIS 3.2 analytical software.

To obtain protein for the cytoplasmic protein analysis, exponentially growing organisms (approximately $10^{7} \mathrm{cel} 1 \mathrm{~s} / \mathrm{m} 1$ ) were harvested at 72 hours post passage and centrifuged at $10,000 \times \mathrm{g}$ for 30 minutes to pellet the cells. Cells were washed once in sterile $0.01 \mathrm{M}$ phosphate buffer $(\mathrm{pH} 7)$ and centrifuged at $10,000 \times 6$ for ten minutes. The cells were resuspended in $2.5 \mathrm{ml}$ sterile $1 \mathrm{mM}$ HEPES $(\mathrm{pH} 7)$ and $2.5 \mathrm{~m} 1$ sterile $0.9 \% \mathrm{NaCl}$ and placed on ice. The cells were broken in a chilled ( $\left.4^{\circ} \mathrm{C}\right)$ Amicon French Pressure cell at $28,000 p s i$. The cell lysate was centrifuged at $3000 \times 6$ for five minutes to remove unbroken cells. The supernatant was collected and concentrated at $4^{\circ} \mathrm{C}$ in Centriprep Protein Concentrators (Amicon) with a molecular weight cutoff of 10,000 daltons. This reduced the total supernatant volume from $5 \mathrm{ml}$ to $500 \mathrm{ul}$. All concentration protocols were carried 
out according to the manufacturer's directions. Concentrated cell lysate was placed on ice.

A $250 u 1$ aliquot of the sample was placed into $1.5 \mathrm{ml}$ microfuge tube to which $500 u l$ of sample buffer was added. The sample buffer consisted of $4 \%$ sodium dodececyl sulfate (SDS), $12 \%$ glycerol, 2\% 2-mercaptoethanol, $0.01 \%$ bromophenyl blue, 1mM phenylmethylsulfonylfluoride (PMSF) (Sigma), and $100 \mathrm{mM}$ dithiothrieitol (DTT) (sigma) in 50mM TRIS-HCl (pH 6.8 ). To reduce viscosity, $1 \mathrm{mg} / \mathrm{ml}$ ( $f$ inal concentration) DNase I (Sigma) was added. The sample was incubated at room temperature for 30 minutes. After incubation, the sample was boiled for 3 minutes at $100^{\circ} \mathrm{C}$ and centrifuged for 2 minutes at $12,000 \times G$. The sample was loaded onto a $12 \%$ discontinuous SDS polyacrylamide gel and electrophoresed at 260 volts for approximately three hours. The gel was fixed in $10 \%$ trichloroacetic acid (TCA) for 1 hour and stained with Coomassie R-250 for 24 hours.

Total cell membranes were prepared as previously described $(25,26,27)$ and analyzed using the SDS polyacrylamide gel electrophoresis technique above with the exception that Triton $x-100$ was added to the membrane sample buffer to give a final concentration of $1 \%$. 
MICROSCOPIC ANALYSIS

Transmission electron microscopy was performed by Ken Tiekotter at the Good Samaritan Hospital Institute of Neuroscience, EM Research Laboratory, Portland, Oregon using a Zeiss EM10-CA transmission electron microscope. Light micrographs were obtained using a Zeiss compound microscope mounted with a Zeiss $C-35$ camera. Unless otherwise indicated, all light micrographs are at a magnification of $1200 x$

\section{METABOLIC ANALYSIS}

Sucrose uptake studies were performed using the standard growth conditions described above. Each flask contained $20 \mathrm{ml}$ of $\mathrm{mBH}$ to which was added $2 \mathrm{uCi}$ of ${ }^{14} \mathrm{C}$-sucrose along with $0.1 \%$ (final concentration) sterile unlabeled sucrose. To selected flasks, succinate ( $\mathrm{pH} 6.8$ ) was added at a final concentration of $0.1 \%$. Cyclic-AMP was added to selected flasks at final a concentration of $1 \mathrm{mM}$. The organisms were allowed to grow for 144 hours (unless otherwise specified) at room temperature with aeration at 100rpm. Harvested cells were washed twice in sterile $0.01 \mathrm{M}$ phosphate buffer ( $\mathrm{pH} 7$ ) before lysis in the French Pressure Cell as described above. One hundred microliters of bacterial cell extract was added to $10 \mathrm{ml}$ of scintillation fluid and counted using a Beckman Model LS-9000 liquid 
scintillation counter. These experiments were performed six times and the data was averaged.

Colorimetric protein assays were performed using a Pierce BCA (Bicinchoninic Acid) Protein Assay Kit following the methods of smith (28). In each assay, a 10047 aliquot of bacterial extract was diluted 1:10, placed in assay buffer per manufacturer's directions and read on an Ultraspec III Spectrophotometer (Pharmacia) at a wavelength of $562 \mathrm{~nm}$. Bovine Serum Albumin (BSA) was used as the standard. Tests for the production of an emulsifying agent or surfactant was done according to the method of Jain (29). In this test, drops of suspended cells or pelleted cells of organisms grown in toluene or sucrose were placed on a sucrose, oil, or solvent-coated surface and observed for the collapse of the pellet or drop of suspended cells, indicating the production of an emulsifying agent or agents or the production of a surfactant. 
RESULTS

IDENTIFICATION OF PC2P15

The soil sample from the contaminated bioremediation pond yielded 42 colony forming units (CFU) by standard plate count techniques. Each CFU was serially diluted in sterile water to approximate 1 y $10^{-8}$ and $1 \mathrm{ml}$ was inoculated into $10 \mathrm{ml}$ capped tubes with $9 \mathrm{ml} \mathrm{mBH}$. Each tube contained a different carbon source as shown in Table III. One isolate, (PC2P15), was found to utilize 13 of the 17 substrates tested.

Growth of P.putida PC2P15 on the various substrates was extremely variable, with lag times ranging from $1 / 2$ hour with several sugars to 31 days with p-amino salicylic acid. (Table III). Concentration of the hydrocarbon was also found to be important. For those organisms from the isolated strain (PC2P15) growing on vapor at the liquid/vapor interface, concentration of the substrate was of no importance. For those organisms growing with the hydrocarbon added directly to the medium, high concentrations of some of the substrates was found to be inhibitory to growth. For example, toluene concentrations in excess of $50 \%(\mathrm{v} / \mathrm{v})$ and phenol concentrations in excess of $5.0 \%(\mathrm{v} / \mathrm{v})$ were found to totally inhibit growth. Growth on alkanes such as unleaded gasoline was not inhibitory up to a $50 \%(v / v)$ concentration. 
Non-volatile substrates such as catechol or 2,4-D showed no differences in growth regardiess of substrate concentration. Concentrations of up to $70 \%(v / v)$ were tried for all volatile and non-volatile hydrocarbons.

Following the substrate testing and limitations experiments, PC2P15 was grown primarily on toluene. Every 10 days the isolate was transferred to a substrate on which it had previously grown, but which required enzymes other than those in the toluene degradation pathway to be utilized. It was found that, in many cases, the organisms had either lost the ability to degrade the newly introduced substrate or needed an exceedingly long lag period before growth began.

\section{GROWTH}

Growth curves (Figure 3 ) are the mean of two identical experiments. Even with an inoculum of bacteria continuously grown in toluene, it can be seen that there was a lag time of approximately 48 hours for toluene-metabolizing organisms and a generation time following the lag period of approximately 24 hours. In contrast, an inoculum of sucrose grown organisms into sucrose showed a lag period of approximately $1 / 2$ hour and a generation time of 2 hours. Qualitatively, the size of the cell pellets after centrifugation were approximately equal regardless of carbon source, and the protein assay revealed a protein content of $491.0 u g / \mathrm{ml}$ for sucrose grown organisms, $621.5 \mathrm{ug} / \mathrm{ml}$ for 


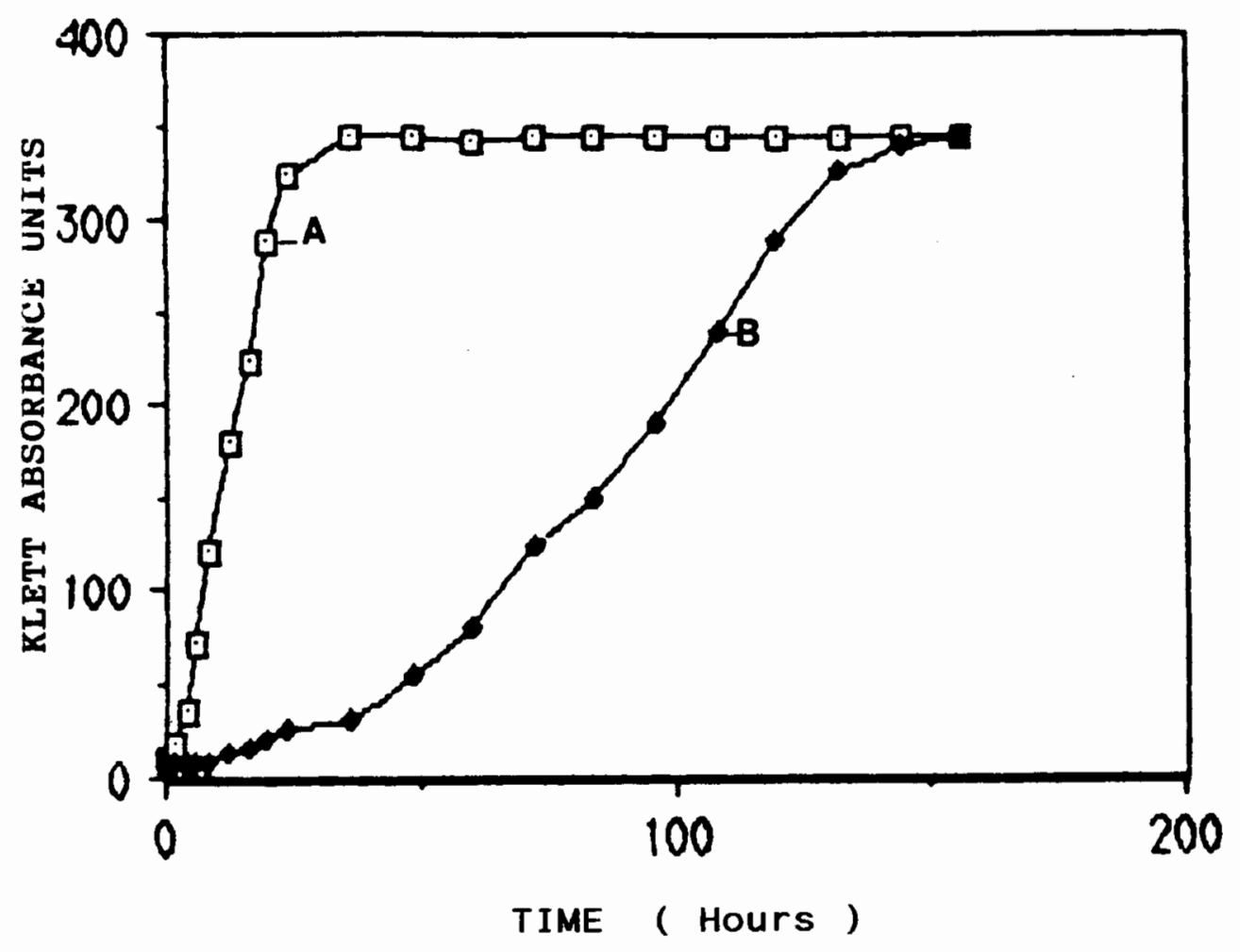

Figure 3. Growth of P.putida PC2P15. A) $\mathrm{mBH}$ with sucrose $0.1 \%$; B) $\mathrm{mBH}$ with toluene vapor 
sucrose and toluene grown bacteria, and $501.5 \mathrm{ug} / \mathrm{ml}$ for sucrose and succinate grown organisms (Figure 4 ). This data represents the average of six identical experiments.

\section{MORPHOLOGY}

The morphology of PC2P15 grown with toluene as its sole source of carbon and energy was very different from the bacterium grown on $\mathrm{mBH}$ with sucrose as its sole carbon source. As shown in Figure 5 , the toluene-grown organisms were approximately $1 / 3$ the size of the cells grown in either sucrose or succinate. The toluene-grown cultures had a tendency to clump together around microdroplets of toluene. Individual bacteria could be observed "bending" around microdroplets of toluene and in direct contact with it. This observation occurred in both vapor-grown cells and in cultures to which toluene had been added directly. Nothing comparable to this clumping and bending phenomenon was observable in the sucrose-grown cells. The organisms were extremely motile in both toluene and sucrose cultures.

Electron microscopy (Figures $6,7,8$ ) revealed the presence of membrane blebs in PC2P15 grown on toluene (Figure 8 ). High magnification $(140,000 x)$ revealed numerous blebs on the outer membrane of all cells examined. The blebs appeared to be surrounded by a bilayer membrane and, in some cases, to be "tethered" to the cell's outer membrane by this same bilayer membrane. Figure 6 shows this bilayer membrane. 


$$
\text { X00ZL: : } 00 ! 7 e 0 !+! 46 \mathrm{ew} \text {-asojons } u !
$$

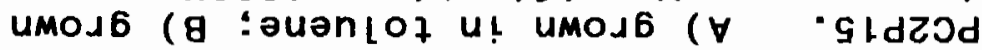

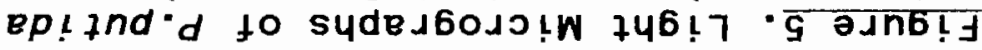
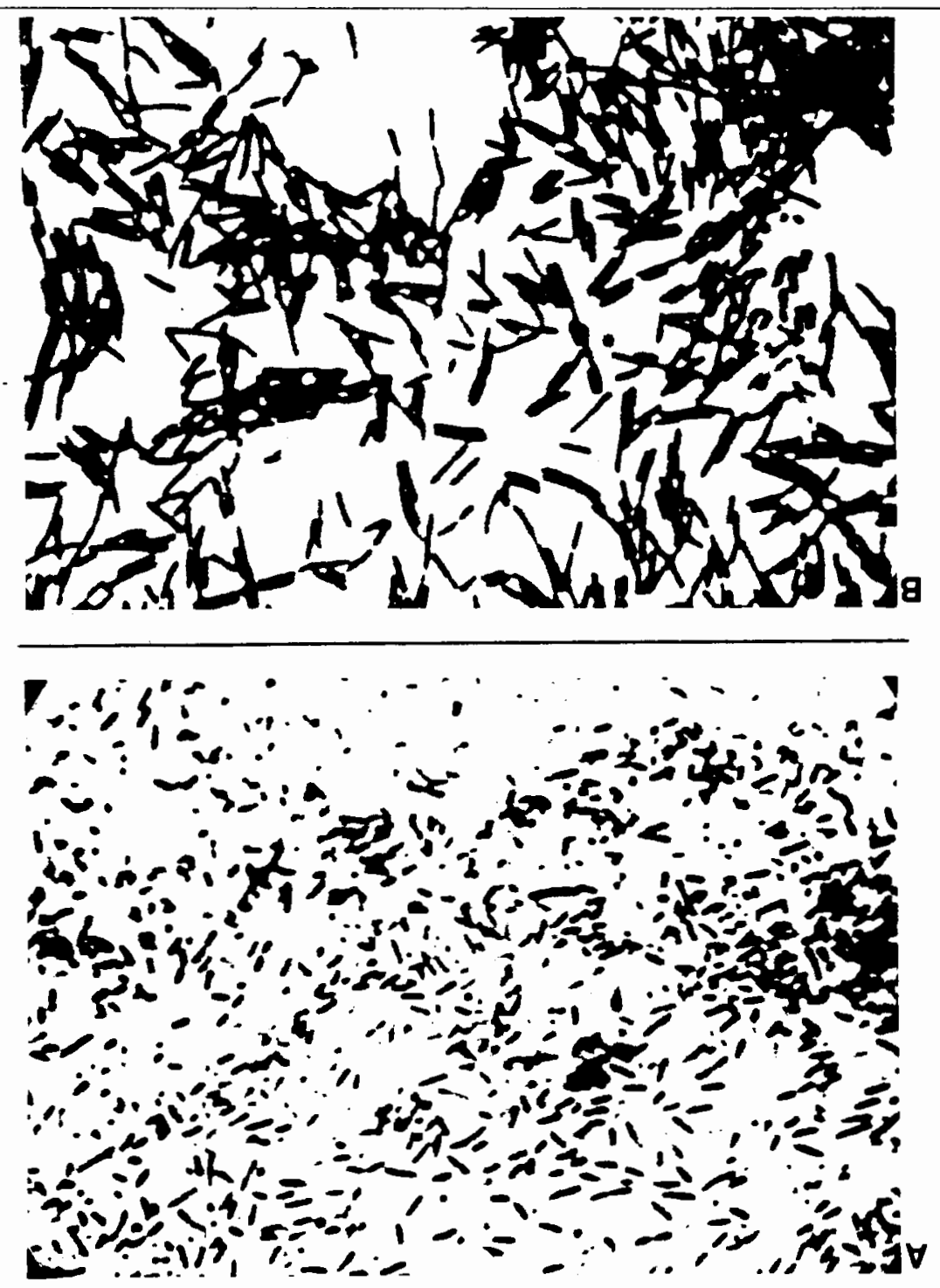


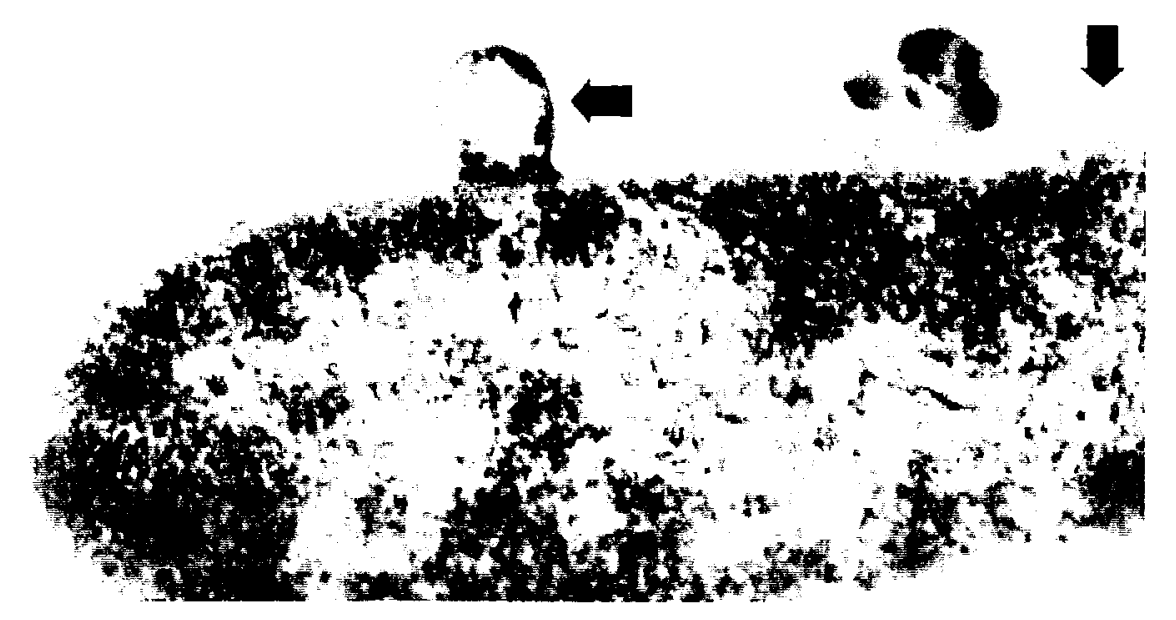

Figure 6. Electron Micrograph of PC2P15 grown in toluene. Arrows indicate membrane blebs and extracellular vesicles. Magnification: $176,000 x$. 


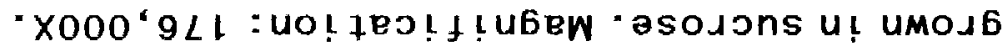

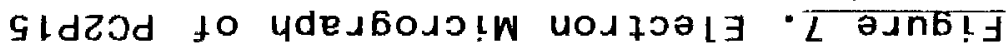

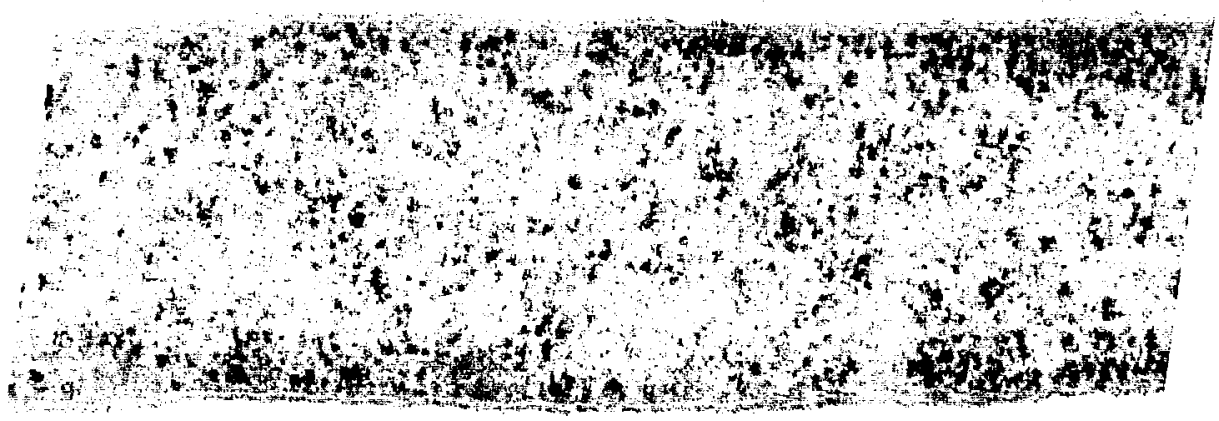




$$
60^{\circ}
$$


The blebs were also been found intact and free-floating in the extracellular milieu. No such physical structures were present in the micrographs of the cells grown on sucrose (Figure 7).

Colony morphology on various agars was typical of Pseudomonas putida. The colonies were small, white, and opaque initially and, after 4 to 5 days of growth, appeared to have a nucleated center with an uneven, ragged edge. On TGYE and nutrient agar, the colonies became slimy after 3-4 days. The organisms were strongly positive for the production of siderophores on CAS agar (55).

Those colonies grown on agar on a Nucleopore filter as described in Materials and Methods did not exhibit this typical morphology. Although colonies were numerous and the bacteria grew readily, the colonies were very small and never nucleated. There was a lag period of approximately 48 hours when transferred to agar and exposed to toluene. Qualitatively, the colonies exposed to toluene appeared slimy. Microscopically, the toluene-grown cells were approximately $1 / 3$ the size of cells grown on agar with sucrose as the carbon source. Colonies growing directly on the agar with sucrose as the carbon source and without the Nucleopore filter had typical P.putida morphology and did not become slimy. Colonies streaked onto a Nucleopore filter with no added carbon source showed no growth. 
PC2P15 grew optimally at approximately $23^{\circ} \mathrm{C}$. Temperatures in excess of $32^{\circ} \mathrm{C}$ showed increasingly slowed growth as a function of increased temperature and there was no growth at $42^{\circ} \mathrm{C}$ as shown in Table II.

Aeration was important in the growth of $\mathrm{PC} 2 \mathrm{P} 15$, especially when grown with toluene. At 100rpm, the growth rate was approximately $25 \%$ faster in those organisms growing on toluene when compared to organisms growing in toluene at $25 \mathrm{rpm}$. Non-aerated organisms exhibited a significantly reduced growth rate when compared to those that were aerated. Aeration appeared to play no role in the growth rate until after the lag period had passed for the hydrocarbon-grown bacteria (ie: the lag period remained 48 hours).

Gross examination of the flask when the organisms were growing in toluene revealed the presence of a slime layer adhering to the sides of the flask. This slime layer was present in all actively growing, exponential phase cultures of toluene-grown organisms at the liquid/vapor interface. Living organisms could be easily recovered from this slime layer with a sterile loop. Centrifugation of liquid cultures grown with toluene were difficult to pellet and had a slimy appearance. Sucrose-grown controls never produced this slime layer and centrifugation produced a firm, non-slimy pellet. When a cell pellet or drop of cell culture grown in toluene was placed on an oil surface it collapsed 
immediately and floated at the surface. Cell pellets or drops of cultures of bacteria grown in sucrose did not collapse and sank within a few seconds. This suggested the production of an emulsifying agent or surfactant by PC2P15 growing in toluene.

\section{FATTY ACID PROFILE}

Fatty acid analysis of the toluene-grown organisms showed a number of significant changes in the membrane fatty acid profile. Figure 9 shows this data compared to the fatty acid profile for cells grown in nutrient broth. Several new fatty acids were synthesized by the toluene-grown bacteria, including octadecanoic and eicosanoic acids. Octadecanoic acid increased from $0 \%$ in the controls to $12.37 \%$ of the total fatty acid content in the toluene-grown cel1s. Conversely, there was a $36 \%$ decrease in undecanoic acid and a 56\% decrease in trans -9 octadecenoic acid. There was a 100\% decrease in nonadecanoic acid in the toluene-grown cells. Two major fatty acid components, dodecanoic and hexadecanoic acids, did not show significant changes when the toluene-grown cells were compared to the controls. The latter two fatty acids account for approximately $55 \%$ of the total fatty acid content of the cells. 


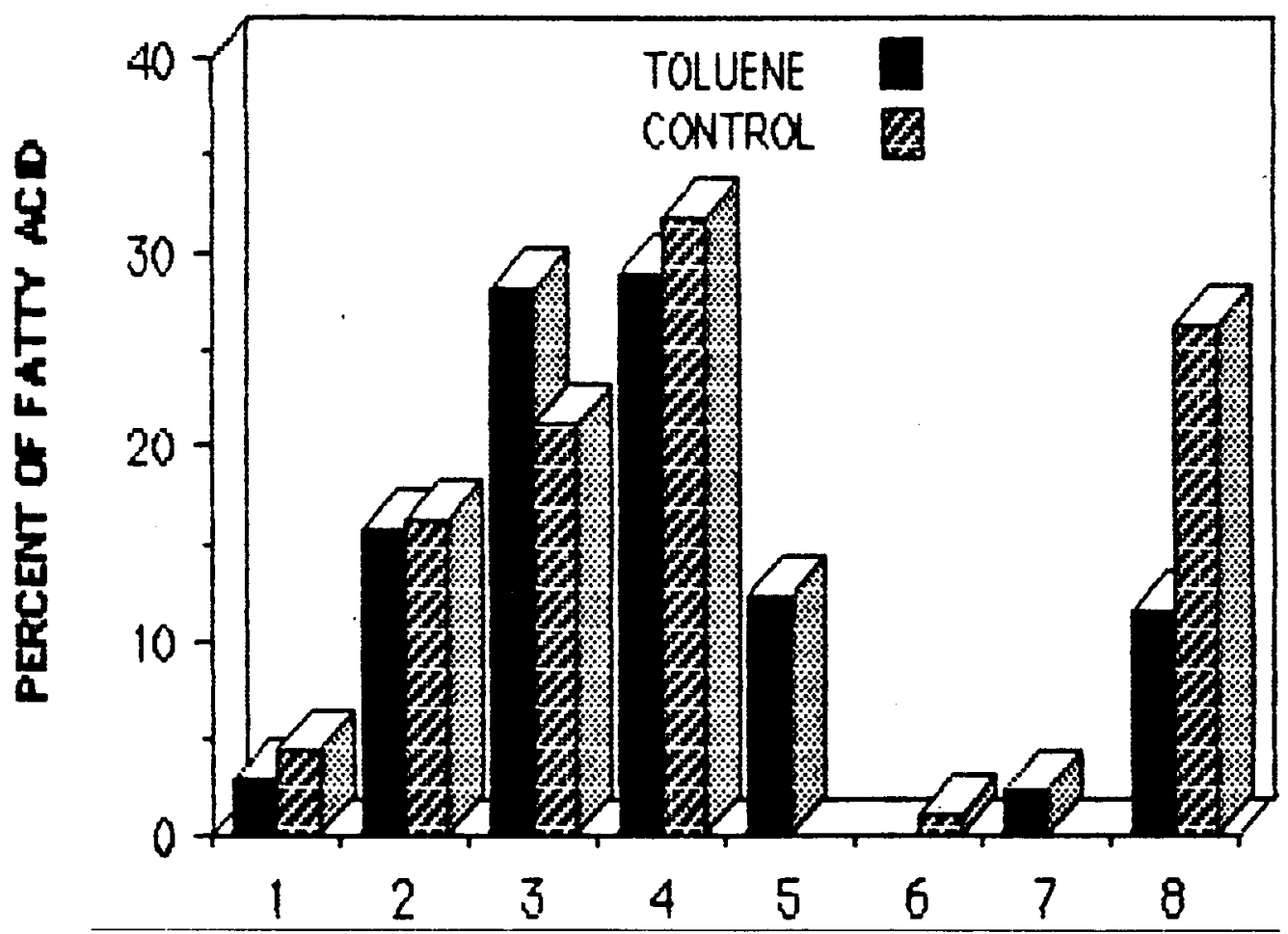

Figure 9. Fatty acid profile of PC2P15. Columns: 1) undecanoic; 2) dodecanoic; 3) 9-hexadecenoic;4) hexadecanoic;

5) oct adecanoic; 6) nonadecanoic;

7) eicosanoic; 8) trans-9 octadecenoic. 
METABOLIC AND PROTEIN ANALYSIS

SDS-PAGE analysis of lysed cells revealed a prominent $65 \mathrm{kd}$ band in toluene-grown cells and the appearance of new bands at $42 \mathrm{kd}$ and $44 \mathrm{kd}$ when compared to cells grown on sucrose, succinate or n-alkanes. Another group of low molecular weight bands ( $<25 \mathrm{kd}$ ) were present in toluenegrown cells, but not present in sucrose-, n-alkane-, or succinate-grown bacteria. A series of eight bands appeared in cells grown on n-alkanes that were not present in sucrose-, succinate-, or toluene-grown cells. A number of bands appeared in sucrose-grown bacteria that were not present in either toluene- or alkane-grown cells. Banding patterns for succinate-grown cells were not significantly different from those grown in toluene.

\section{CATABOLITE REPRESSION}

Studies were done to determine the rate of ${ }^{14} \mathrm{C}$-sucrose uptake in cells in the presence of toluene, succinate, or toluene plus succinate. We also tested the effect of cyclicAMP on ${ }^{14} \mathrm{C}$-sucrose uptake with various combinations of these substrates.

Exponentially growing cells using toluene as the sole source of carbon and energy were inoculated in media with various carbon sources as shown in Table IV. The flasks were 


\section{TABLE IV}

${ }^{14} \mathrm{C}$-SUCROSE UPTAKE IN PC2P15

FLASK \# FLASK CONTENTS**

1 SUCROSE

2 SUCROSE/TOLUENE

3 SUCROSE/TOLUENE/SUCCINATE

4 SUCROSE/TOLUENE/C-AMP

5 SUCROSE/C-AMP

6 SUCROSE/SUCCINATE

7 SUCROSE/SUCCINATE/C-AMP

8 SUCROSE/SUCCINATE/TOLUENE/C-AMP

9 FLASK 3 W/SUCROSE INOCULUM

10 FLASK $3 \mathrm{~W} /$ TOLUENE INOCULUM
CPM/mg protein*

46,000

23,000

9,000

25,000

44,000

24,000

23,000

10,000

12,000

10,000

* cPm rounded to nearest 1000.

**FINAL CONCENTRATIONS IN INDICATED FLASKS:

Sucrose $0.1 \%$; Succinate $0.1 \%$; C-AMP $1 \mathrm{mM}$;

Toluene as vapor 
incubated as described in Materials and Methods. The data in Figures 10 and 11 and the data in Table IV represent the average of 6 separate experiments.

When toluene or succinate was present in the medium containing sucrose (Flasks 2 and 6 ), the $\mathrm{cpm} / \mathrm{mg}$ protein was decreased by approximately $50 \%$ compared to medium containing sucrose alone. Since succinate is reported to be a catabolite repressor in Pseudomonas (62), C-AMP was added to flasks containing sucrose and toluene (Flask 4 ), sucrose and succinate (Flask 7 ), sucrose alone (Flask 5 ) and sucrose, toluene, and succinate (Flask 8 ). It can be seen that C-AMP had no affect. It can also be seen that cultures grown with sucrose, succinate, and toluene without c-AMP (Flask 3 ) showed on 1 y $25 \%$ of the $\mathrm{cpm} / \mathrm{mg}$ protein when compared to sucrose alone (Flask 1). Again, the addition of c-AMP (Flask 8) had no affect on uptake.

A separate experiment comparing an inoculum of sucrosegrown bacteria versus an inoculum of bacteria grown in toluene (Flasks 9 and 10 ) showed the same effect regardless of previous growth. The bacteria grown in sucrose had been transferred 4 times on sucrose prior to use as the inoculum.

Since the initial experiments were harvested at 144 hours, two identical experiments were done and the cells harvested at 24 and 48 hours. Time of harvest was shown to be of no importance and ${ }^{14} \mathrm{C}$-sucrose was reduced by $50 \%$ and 75\% as previously observed. 
I. 


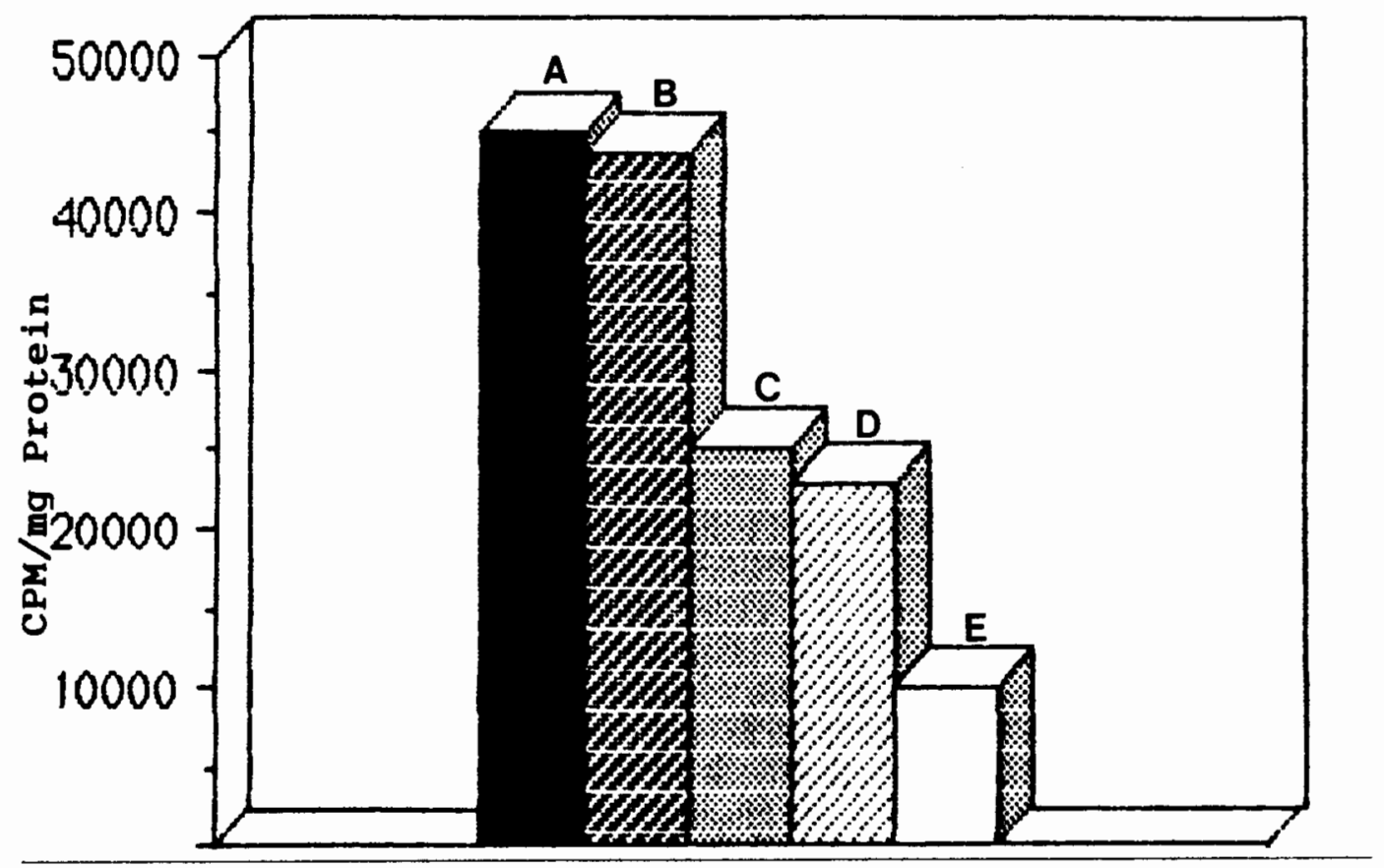

Figure $11 .{ }^{14} \mathrm{C}$-Sucrose uptake in $P$.putida with cyclic-AMP added. A) Sucrose (no c-AMP); B) Sucrose; C) Sucrose/Toluene; D) Sucrose/ Succinate; E) Sucrose/Succinate/Toluene. 
Isotope balance showed that the amount of ${ }^{14} \mathrm{C}$-sucrose remaining in the supernatant in toluene, succinate, or toluene/succinate cells was proportionally higher than the sucrose cells. In addition, the proportion of the original quantity of ${ }^{14} \mathrm{C}$-sucrose not present in either the pellet or the supernatant was lower in toluene, succinate, and toluene/succinate cells when compared to sucrose controls. The ${ }^{14} \mathrm{C}$ not present in pellet or supernatant appears to have been respired by the cells in quantities that are approximately proportional to the observed uptake and utilization data in Table IV and in Figures 8 and 9 . This suggests that ${ }^{14} \mathrm{C}$-sucrose was not respired at the rate in sucrose/toluene, the sucrose/succinate, or the sucrose/succinate/toluene cells at the rate it was being respired in the sucrose controls. 


\section{DISCUSSION}

\section{MORPHOLOGY AND METABOLIC STRESS}

The general morphology of organisms growing under laboratory conditions as opposed to those growing in natural environments has recently been reviewed by Roszak (30). In this excellent article, Roszak suggests that morphological changes, such as the reduction in size and slower growth rate that we have observed in our toluene grown organisms, may be closer to the natural state of bacteria in the environment. Roszak suggests that laboratory control organisms may, in fact, be abnormally large with an artificially high reproductive rate because of the unlimited access to nutrients and carbon sources rarely found in a natural setting.

Bacteria growing in a metabolically stressed environment may be viable but non-culturable (30). There are changes in fatty acid content, RNA, cellular DNA, and protein content in bacteria that are metabolically stressed or near starvation $(31,32)$. It has been suggested that smaller size maximizes nutrient uptake by way of an increased surface area to volume ratio. In one study, DNA content in starved cells dropped to $5.2 \%$ of the original quantity after 98 days of starvation (31). 
Bacteria in the natural environment may have a number of survival mechanisms, including the production of endospores. It has been hypothesized that bacteria unable to produce an endospore may have a non-spore survival stage in which they enter a period of dormancy with extremely low metabolic rates ( 30 ). In this state they are considered viable but non-culturable. Given an adequate nutrient supply and an easily assimilated substrate such as pyruvate, there is a rapid increase in intracellular ATP followed by an increase in motility, cellular DNA content, cellular size, and finally cell division following a lag period that is dependent on the type of organism present and the available substrate (30). This period of dormancy, in which the surviving bacteria (estimated at $2-4 \%$ of the original population) are believed to metabolize the cellular contents of lysed bacteria, has been termed cryptic growth (30).

The observations above could explain some of our findings with regard to the toluene oxidizing organism PC2P15. Organisms transferred from a minimal salts medium with sucrose to a minimal salts medium with toluene undergo a lag period of as long as 10 days before growth begins again. Microscopic examination of the first post-transfer exponential stage reveals that most of the organisms appear to have reduced their size by $1 / 2$ to $2 / 3$ compared to the size of the bacteria in the inoculum. This might indicate that PC2P15 does not use toluene as efficient 1 y as sucrose 
and reduces its size to increase its surface area to volume ratio. It may also indicate membrane damage as a result of toluene exposure and a resulting decrease in the efficiency of uptake of the toluene substrate.

In addition, we have experienced occasional difficulty regaining culturable organisms with the ability to metabolize toluene when sucrose-grown bacteria were transferred to toluene. This observation may be due in part to the fact that pseudomonads have a tendency to spontaneously lose plasmids over a period of time when grown in substrates other than those coded for on the plasmid. Summmers (48) observed a failure to maintain plasmids in high copy numbers over time, and Cohen (49) detected a loss of plasmids in daughter cells following cell division. Keshavarz (56) noted a residual of only $1 \%$ of the population retained the m-toluate plasmid after 600 hours of growth in benzoate. We have found that increasing the initial inoculum size from $1 \mathrm{ml} / 20 \mathrm{ml}$ to $10 \mathrm{~m} 1 / 20 \mathrm{~m} 1$ great $1 \mathrm{y}$ enhances the recovery of toluene-oxidizing organisms from a sucrose culture. This suggests that only a small percentage of inoculated bacteria may have retained the ability to degrade toluene after a period of time using sucrose as a substrate. A second possibility is that there is an extended 1 ag period when the alternate substrate is a hydrocarbon requiring a different degradative pathway. Lag times of up to 6 months have been reported for certain strains of bacteria (61). The 
mechanism behind sudden exponential growth after a 1 ag period of weeks or months remains in doubt.

A number of researchers have shown both interior and exterior morphological changes for organisms metabolizing hydrocarbons. In a species of Acinetobacter, scott and others $(50,51,52)$ found membrane-bound inclusion bodies in organisms metabolizing hexadecane. It is believed that these structural changes, which include the membrane-surrounded inclusion bodies, an intra-cytoplasmic membrane, and the production of extracellular vesicles, have a direct bearing on the utilization of hydrocarbons as sources of carbon and energy.

Electron micrographs of PC2P15 did not reveal the presence of either an intracytoplasmic membrane or hydrocarbon inclusion bodies. It did, however, reveal what appear to be blebs on the surfaces of cells grown in toluene as the sole source of carbon and energy. In addition to blebs on the surfaces of the cells, a number of these membrane-enclosed structures were observed free in the extracellular milieu. Kappeli (53) has noted similar extracellular vesicles in hexadecane-grown Acinetobacter and in a species of Pseudomonas. Because of the toxicity of toluene to most microorganisms, we initially suspected that this bleb phenomenon might have been a mechanism of membrane sloughing and repair because we observed an intact membrane beneath the blebs. We further speculated that the blebs 
might have been the result of cell shrinkage. We now suggest that these blebs may be extracellular vesicles possibly involved in the emulsification and partitioning of toluene for use by the bacterium.

Experiments currently in progress in our laboratory in which sterile filtered medium from an exponentially growing culture of PC2P15 is used as the starting media for a fresh inoculum of PC2P15, have shown promising preliminary results. The lag time for toluene-grown organisms is reduced from approximately 48 hours to approximately 6 hours. This may indicate the presence in the medium of a bacterial product or products that assists with the partitioning, emulsification, or uptake of the toluene substrate. If this is the case, it would help to explain the characteristic 48 hour lag phase in transfers of exponentially-grown toluene organisms into toluene. Although the toluene-grown organisms have a much slower growth rate than the sucrose-grown cel1s, this does not adequately explain the 48 hour period of no growth or minimal growth we have observed. We suggest that these organisms may "condition" the medium by creating a microemulsion of toluene through the release of an as yet unidentified agent or agents into the medium by way of the observed membrane vesicles. Other pseudomonads are known to release a rhamnolipid emulsifying agent when grown on alkanes to increase the solubility of the alkane (53). There is reason to suggest that a similar mechanism to 
solubilize toluene may operate in PC2P15. The slimy biofilm observed at the liquid/vapor interface where those organisms were growing in toluene may have been part of the visible manifestation of those emulsifying agents. The biofilm may also have served to allow the organisms to adhere to the sides of the flasks at the 1 iquid/vapor interface where they were continuously bathed in nutrients from the agitation of the rotating shaker. We are now attempting to identify both the nature of the membrane blebs and of the biofilm produced by the bacteria.

\section{CYTOPLASMIC PROTEINS}

Total protein in the cell pellet of organisms grown on toluene was approximately the same as the protein content in the cell pellet of organisms grown on sucrose, sucrose and toluene, or sucrose, toluene, and succinate. These results support our observation and the observation of other researchers (31) that, although the toluene-grown cells were smaller than sucrose grown cells, total protein content was approximately equal in the cell pellets and that the number of cells in the population was equal to or higher than the sucrose grown cel1s. It was important to ascertain cell density by both the turbidity of the cultures and by assay of total protein content to properly interpret our findings in the sucrose uptake and SDS-PAGE studies. 
SDS-PAGE of the cell lysate revealed that sucrose-grown cells produced a banding pattern significant $7 y$ different from cells grown on toluene. Prominent bands of about $65 \mathrm{kd}$, $42 \mathrm{kd}, 44 \mathrm{kd}$, and several bands below $25 \mathrm{kd}$ that were not present in either the sucrose or the alkane grown cells were observed in cells grown on the aromatics toluene, benzene, and phenol. These findings suggest the activation of genes involved in the acquisition or degradation of aromatics. It is reasonable to assume that these and other new bands present in the aromatic grown cells were enzymes or structural proteins involved in either the degradation of toluene, benzene and phenol or as a result of exposure to these substances. In the case of phenol, we might expect to find a monooxygenase being used due to the presence of the hydroxyl group present on the ring, but a banding difference between toluene and phenol was not seen. However, the use of the dioxygenase system, resulting in a triple hydroxylation followed by a dehydration to form the catechol, cannot be ruled out at present.

A series of 8 bands appeared in the alkane-grown cells that were not present in the aromatic- or sucrose-grown cells. When the cells were grown with sucrose and toluene, the banding pattern was a composite of the banding patterns of the two separate carbon sources but the sucrose bands were less intense. Lysates of organisms grown in toluene, sucrose, and succinate showed no change in banding from that 
of the sucrose/toluene grown cells. This result might be expected from the addition of succinate, a krebs cycle intermediate, that would not necessarily require the induction of new catabolic enzymes.

METABOLISM OF MULTIPLE CARBON SOURCES

Our data suggest that both sucrose and toluene are catabolized by inducible enzyme systems, and that PC2P15 has the capacity to use both carbon sources at the same time. A recent study (54) indicated that Pseudomonas strain JS6 has the capacity to simultaneously metabolize both chlorobenzene and toluene which requires the concurrent induction of two metabolic pathways. The former entails an ortho-fission pathway and the latter uses a meta-fission pathway. It was previously believed that these two pathways were incompatible. Another organism, Alcaligenes eutrophus JMP 134 , has been shown to use three pathways at once (54). This organism utilizes an ortho-, modified ortho-, and a metafission pathway simultaneously.

our ${ }^{14} \mathrm{C}$-sucrose uptake studies have indicated that PC2P15 may utilize toluene, sucrose, and succinate simultaneously. It is known that the membrane protein, succinic dehydrogenase, is produced constitutively in many bacteria, including the pseudomonads. The metabolic pathway for sucrose, if not constitutive, would require the induction of enzymes like phosphotransferase and others 
necessary for sucrose uptake and ut ilization. It is not known whether the enzymes of the Entner-Doudoroff pathway are produced constitutively in this particular strain after a period of growth on a toluene substrate requiring a different degradative pathway.

Succinate, which is known to be a catabolite repressor in $P$. putida (62), depressed sucrose uptake approximately $50 \%$ in cells exposed to both sucrose and succinate. It is unclear why the presence of cyclic-AMP did not derepress sucrose uptake in cultures of sucrose and succinate or in cultures of sucrose and toluene if either succinate or toluene were acting as catabolite repressors.

Our results indicated an activation of both the toluene and sucrose enzyme systems in organisms with both toluene and sucrose as simultaneously available carbon sources. When succinate was added to toluene and sucrose cultures, ${ }^{14} \mathrm{C}-$ sucrose uptake was depressed by an additional 20-25\% of that with sucrose and toluene alone. This suggests the simultaneous use of three distinct carbon sources in the same organism. It is possible that a feedback mechanism operates in PC2P15 to decrease the uptake of ${ }^{14} \mathrm{C}$-sucrose in the presence of abundant krebs intermediates derived from the uptake and utilization of toluene and/or succinate. Our data suggest that the enzymes of the Entner-Doudoroff pathway, the proteins required for succinate uptake and 
utilization, and the pathway necessary for the catabolism of toluene are simultaneously operative in PC2P15.

Another possibility is that, in any given population of bacteria, individual bacteria may be utilizing only one of the two or three available carbon sources. For example, in a flask of PC2P15 exposed to toluene, succinate, and sucrose, $25 \%$ of the bacteria may be using sucrose, $50 \%$ may be using toluene, and $25 \%$ using succinate. This possibility cannot be dismissed although our consistent results suggest the simultaneous use of multiple carbon sources by PC2P15.

Studies are planned in our laboratory that we hope will further elucidate how PC2P15 utilizes multiple carbon sources and the mechanisms involved. In addition, we hope to use monoclonal antibodies to the mono- and dioxygenases and to cis-toluene dihydrodiol dehydrogenase to elucidate both the roles and locations of these enzymes intracellularly or in the membrane vesicles. 


\section{CONCLUSIONS AND SUMMARY}

A strain of Pseudomonas has been isolated from a bioremediation pond and identified as a Pseudomonas putida which we have designated strain PC2P15. This organism has exhibited the ability to use a number of aliphatic hydrocarbons, aromatics, and other substrates as the sole sources of carbon and energy.

Our results have shown significant changes in the fatty acid content, the synthesis of proteins, the growth rate, and the morphology of these bacteria when using toluene as the sole source of carbon and energy when compared to cells grown in sucrose. We have observed membrane blebs or extracellular vesicles attached to the outer surface of cells and also in the extracellular milieu of toluene-grown organisms. We believe these blebs may be involved in the emulsification and partitioning of the toluene substrate for use by the bacteria.

Our results also indicated the simultaneous use of multiple carbon sources by PC2P15. ${ }^{14} \mathrm{C}$-sucrose uptake was decreased by $50 \%$ when cells were grown with sucrose and toluene or in sucrose with succinate. Our results have also shown an additional 20-25\% drop in sucrose uptake when succinate was added to a sucrose/toluene culture. 
In light of the increasing toxic contamination of both soil and water in the world today, science is striving to understand the role of microorganisms in the degradation of xenobiotics. Even though many bacteria possess the metabolic capacity to use hydrocarbons, the pseudomonads have a particularly wide range of metabolic abilities which are of interest to microbiologists.

Although a great deal of information has been gathered over the past several decades on the physiology, biochemistry, and genetics of biodegradative bacteria, much more work still lies ahead. It is not enough to study these organisms in the laboratory. To fully understand how these cells operate, they must be studied in situ. Because isolated organisms in the laboratory probably function in a very different manner from those in the environment, a complete understanding of the bioremediation of contaminated soils and water by microorganisms will come only from the study of these organisms in their natural habitats and with proper consideration given to their relationships to other organisms and to the abiotic conditions present in their environment. A complete and long term effort is necessary to study these organisms in both amended and unamended environments in situ to compliment the information obtained from the laboratory.

It is of interest that our isolate may have the capability to metabolize multiple carbon sources simul- 
taneously. In the environment, concurrent metabolism of several carbon sources might have a survival advantage for those organisms that have evolved these abilities. If our isolate also has the capability to secrete emulsifying agents or enzymes into the environment in a manner similar to the release of iron-chelating siderophores, it would gain a definite evolutionary advantage over those bacteria without these heritable traits.

Because an entire bacterial community can exist and evolve on a single grain of soil to which a particular substrate has adhered, it is difficult to follow the progress of a single population of organisms in situ. We hope that, over the next few years, science will develop the technical expertise to observe and understand the actions and interactions of microorganisms in situ and gain insights into their exceedingly complex and vital role in the degradation of naturally occurring substances and xenobiotics in the environment. 


\section{REFERENCES}

(1) Eastern Research Group, Inc. (1989). Alaskan Oi1 Spi11 Bioremediation Project. In: Ecol.Res.Ser. U.S. Environmental Protection Agency.

(2) Hil1, D.L., et al (1989). Biochem.Biotechnol. 20-21, 233-244.

(3) Von Wedel, R.J., et al (1988). Water Science Technol. $20: 11-12,501-503$.

(4) Ridgway, H.F., et al (1990). Applied Microbiology Biotechnology. $34: 2,248-252$.

(5) Leahy, J.G. and R.R. Colwel1 (1990). Microbio7. Rev. $54: 3,305-315$.

(6) Premuzik, E.T. and M.S. Lin (1991). Resources Conservation and Recycling. 5:2-3, 167-182.

(7) VanDenmark, Paul J. and B.J. Batzung (1987). The Microbes. Benjamin Cummings Pub. Co.. 497-499.

(8) Blumer, M. and W.W. Youngblood (1975) Science. vol. 188. 53-55.

(9) Hites, R.A., et al (1977). Science. vol. 198. 829-831.

(10) Reineke, W. (1984). In: Microbial Degradation of Organic Compounds. D.T. Gibson (ed.). 319-360.

(11) Chapman, P.J. (1988). In: Environmental Biotechnology: Reducing the Risks from Environmental Pollution Through Biotechnology. G.S. Omenn (ed.). 81-95.

(12) Timmis, K.N., et al (1988). In: Environmenta 7 Biotechnology: Reducing the Risks from Environmental Pollution Through Biotechnology. G.S. Omenn (ed.). 6179.

(13) Ihoue, Akira and Koki Horikoshi (1989). Nature. 338, 264- 266 .

(14) Dagley, Stanley (1978). Q. Rev. Biophys. 11, 577-602. 
(15) Anderson, J.J. and S. Dagley (1981). J. Bacteriol. 146, 291-297.

(16) Gibson, D.T., et al (1968). Biochemistry. 7:2653.

(17) Gibson, D.T., et al (1970). Biochemistry. 9:1631.

(18) Hogn, T., et a 1 (1972). Eur. J. Biochem. 30:369.

(19) Dagley, Stanley (1986). In: The Bacteria: A Treatise on structure and Function. J.R. Sokatch (ed.). Academic Press 527-555.

(20) Stanier, R.Y., et al (1966). J. Gen. Microbiol. 43, 159-271.

(21) Slater, J.H. and D.J. Hardman (1982). In: Experimental Microbial Ecology. R.G. Burns and J.H. Slater (eds.). Blackwe11, Oxford. 255-274.

(22) Sato, T., et al (1963). J. Biochem. 52:23.

(23) Jerina, D.M., et al (1968). Arch. Biochem. Biophys. $128: 176$.

(24) Dagley, Stanley (1986). In: The Bacteria: A Treatise on structure and Function. J.R. Sokatch (ed.). Academic Press. 527-555.

(25) Methods in Enzymology. (1974). S. Fleischer and L. Packer (eds.). Vol. 31. Academic Press.

(26) Methods in Enzymology. (1984). W, B. Jacoby (ed.). Vol. 104. Academic Press.

(27) Pakrasi, T., et al (1979). Proc.Nat.Acad.Sci. Vol. 82. 6903-6907.

(28) Smith P.K., et al (1985). Anal. Biochem. 150: 76-85.

(29) Jain, D.K., et al (1991). Journal of Microbiological Methods. 13:4, 271-280.

(30) Roszak, D.B. and R.R. Colwell (1987). Microbiological Reviews.

(31) Moyer, Craig L. and Richard I. Morita (1989). Applied and Environmental Microbiology. 55:10, 2710-2716.

(32) Linder, Katherine and James D. Oliver (1989). Applied and Environmental Microbiology. 55:11, 2837-2842. 
(33) Yen, Kwang-Nru, et a (1991). J. Bacterio7. 173:17, 5315-5327.

(34) Rogers, J.E. and D.T. Gibson (1977). J. Bacteriol. 130:3, 1117-1124.

(35) Collingsworth, william L., et al (1973). J. Bacteriol. $113: 2,922-931$.

(36) Whited, Gregory M. and David T. Gibson (1991). J. Bacterio7. 173:9, 3010-3016.

(37) Crutcher, Stephen E. and Phillip J. Geary (1979). Biochemical Journa7. 177, 393-400.

(38) Subramanian, V., et al (1981). The Journal of Biological Chemistry. 256:6, 2723-2730.

(39) Gibson, D.T., et al (1970). Biochemistry. 9:7, 16311635.

(40) Gibson, D.T., et al (1970). Biochemistry. 9:7, 16261630 .

(41) Madsen, Eugene L., et al (1991). Science. 252:10, 830833 .

(42) King, J.M.H., et al (1990). Science. 251:17, 778-781.

(43) Claxton, Larry D., et al (1991). Nature. 353, 24-25.

(44) Brumsbach, F.R. and W. Reineke (1990). Applied Microbiology and Biotechnology. 34:2, 248-252.

(45) Heitkamp, M.A., et al (1990). Applied and Environmental Microbiology. 56:10, 2967-2973.

(46) Pettigrew, C.A., et al (1990). Applied and Environmental Microbiology. 57:7, 2036-2045.

(47) Ramos, Gonzalez M.I., et al (1991). Applied and Environmental Microbiology. 57:10, 3020-3027.

(48) Summers, D.K. and D. Sherratt (1984). Ce71.36, 10971103.

(49) Cohen, S.N., et al (1985). In Plasmids in Bacteria. D.R. Helinski, S.N. Cohen, D.B. Clewel1, D.A. Jackson, and A. Hollaender (eds.). Plenum. 189-214.

(50) Scott, Christina C.L. and W.R. Finnerty (1976). J. Bacterio7. 127:1, 481-489. 
(51) Scott, Christina C.L., et al (1976). J. Bacteriol. $127: 1,469-480$.

(52) Scott, Christina C.L. and W.R. Finnerty (1976). Journal of General Microbiology. 94, 342-350.

(53) Kappe 1 , O. and W.R. Finnerty (1979). J.Bacteriol. $140: 2,707-712$.

(54) Pettigrew, Charles A., et al (1991). Applied and Environmental Microbiology. 57:1, 157-162.

(55) Schwyn, Bernhard and J.B. Neilands (1987). Analytica7 Biochemistry. 160, 47-56.

(56) Keshavarz, T., et al (1985). Journal of General Microbiology. 131, 1193-1203.

(57) Goldstein, Rebecca M., et al (1985). Applied and Environmental Microbiology. 50:4, 977-983.

(58) Alvarez, Pedro J.J. and Timothy M. Vogel (1991). Applied and Environmental Microbiology. 57:10, 29812985.

(59) Sander, Peter, et al (1991). Applied and Environmental Microbiology. $57: 6,1430-1440$.

(60) Lindstrom, Jon E., et a 1 (1991). Applied and Environmental Microbiology. 57:9, 2514-2522.

(61) Linkfield, Timothy G., et al (1989). Applied and Environmental Microbiology. 55:11, 2773-2778.

(62) The Microbial World 4th Ed. (1976). R.Y.Stanier, E.A. Adelberg, and J.L. Ingram (eds.). Prentice-Hal1. pp 257 .

(63) 0 il in the Sea: Inputs, Fates, and Effects (1985). National Academy Press. Washington, D.C.. p 47. 